\title{
EKSPLANASI ILMIAH DAMPAK EL NINO LA NINA
}

\author{
Rosmiati \\ STKIP Bima
}

Citasi: Rosmiati. 2017. Eksplanasi Ilmiah El Nino LA. Mangifera Edu Volume 2 Nomor 1, Juli 2017. Hal 32-41

\begin{abstract}
ABSTRAK
Indonesia sebagai salah satu negara yang memiliki pulau pulau besar dan kecil berada di daerah tropis, menerima radiasi matahari paling banyak serta dipengaruhi oleh berbagai fenomena atmosfer menyebabkan wilayah ini rentan terhadap variabilitas dan perubahan iklim. Iklim di Indonesia tidak akan selalu berjalan secara normal setiap tahunnya, ada suatu saat terjadi penurunan curah hujan namun di saat yang lain terjadi curah hujan yang tinggi sehingga menyebabkan banjir. Sebagian masyarakat beranggapan bahwa terjadinya banjir dan kemarau panjang diakibatkan oleh dosa-dosa manusia, diantaranya adanya berjudi, membunuh, merampok dll. Hal ini memerlukan Eksplanasi Ilmiah agar dapat memberikan jawaban terhadap pertanyaan-pertanyaan tentang adanya penyebab penurunan curah hujan atau terjadi nya kekeringan dan terjadinya curah hujan atau bencana banjir di Indonesia. Sesuatu dieksplanasi secara ilmiah jika memenuhi dua syarat, yaitu syarat relevan eksplantori dan syarat testabilitas, syarat pertama eksplanasi ilmiah dapat terpenuhi dengan menggunakan penjelasan dan pengertian El Nino dan La Nina yang merupakan salah satu bentuk penyimpangan iklim di Samudera Pasifik yang ditandai dengan kenaikan suhu permukaan laut di daerah katulistiwa bagian tengah dan timur, Sedangkan La Nina sebaliknya dari El Nino. Dengan penjelasan dan pengertian El Nino dan La Nina yang memenuhi syarat kedua eksplanasi ilmiah yaitu dampak El Nino adalah terjadinya kekeringan dan dampak El Nina adalah terjadinya musim hujan. Hal ini sesuai dengan hakikat pembuktian keilmuan adalah kepercayaan bahwa suatu pernyataan dan pengertian mempunyai peluang besar untuk terbukti ataubenar.
\end{abstract}

Kata-kata Kunci: Eksplansi Ilmiah, El Nino La Nina, Iklim.

\section{PENDAHULUAN}

Indonesia sebagai salah satu negara yang memiliki pulau pulau besar dan kecil berada di daerah tropis, menerima radiasi matahari paling banyak serta dipengaruhi oleh berbagai fenomena atmosfer menyebabkan wilayah ini rentan terhadap variabilitas dan perubahan iklim. Iklim dapat didefinisikan sebagai kondisi rata-rata suhu udara, curah hujan, tekanan udara, arah angin, kelembaban udara dan parameter iklim lainnya dalam jangka waktu yang panjang (Tjasyono,2004). Dua unsur utama iklim adalah suhu udara dan curah hujan. Suhu udara memiliki variabilitas yang kecil sedangkan curah hujan sebaliknya memiliki variabilitas yang cukup besar. Curah hujan tahunan cukup tinggi juga terjadi di Indonesia, sehingga curah hujan sering dijadikan objek penelitian dibandingkan unsur iklim yang lain. 
Iklim di Indonesia tidak akan selalu berjalan secara normal setiap tahunnya, ada suatu saat terjadi penurunan curah hujan namun di saat yang lain terjadi curah hujan yang tinggi sehingga menyebabkan banjir. Secara umum penyebab curah hujan di Indenesia di pengaruhi oleh beberapa fenomena diantaranya El Nino dan La Nina. Fenomena El Nino ditandai oleh terjadinya pergeseran kolam hangat yang biasanya berada di perairan Indonesia ke arah timur (Pasifik Tengah) yang diiringi oleh pergeseran lokasi pembentukan awan yang biasanya terjadi di wilayah Indonesia ke arah timur yaitu di Samudra Pasifik Tengah Dengan bergesernya lokasi pembentukan awan tersebut, maka timbul kekeringan yang berkepanjangan di Indonesia(Accaps,2016).

Sebagian masyarakat beranggapan bahwa terjadinya banjir dan kemarau panjang diakibatkan oleh dosa-dosa manusia, diantaranya adanya berjudi, membunuh, merampok dll. Padahal fenomena banjir dan kekeringan diakibatkan oleh kejadian el nino la nina. Berdasarkan pemaparan di atas, diketahui bahwa fenomena El Nino La Nina di wilayah benua maritim Indonesia menghasilkan pengaruh yang berbeda di setiap tempat sehingga posisi suatu wilayah menentukan pula kadar pengaruh fenomena ini, sehingga anggapan mansyarakat tentang bencana banjir dan kekeringan bisadijelaskan.

\section{HASIL DAN PEMBAHASAN}

\section{Pengertian EI Nino Dan La Nina}

El-Nino (bahasa Spanyol) sendiri dapat diartikan sebagai "anak lelaki". Di kemudian hari para ahli juga menemukan bahwa selain fenomena menghangatnya suhu permukaan laut, terjadi pula fenomena sebaliknya yaitu mendinginnya suhu permukaan laut akibat menguatnya upwelling. Kebalikan dari fenomena ini selanjutnya diberi nama La-Nina (juga bahasa Spanyol) yang berarti "anak perempuan" El Nino dan La Nina adalah merupakan dinamika atmosfer dan laut yang mempengaruhi cuaca di sekitar laut Pasifik. El Nino merupakan salah satu bentuk penyimpangan iklim di Samudera Pasifik yang ditandai dengan kenaikan suhu permukaan laut di daerah katulistiwa bagian tengah dantimur.

Sebagai indikator untuk memantau kejadian El Nino, biasanya digunakan data pengukuran suhu permukaan laut pada bujur $170^{\circ} \mathrm{BB}-120^{\circ} \mathrm{BB}$ dan lintang $5^{\circ} \mathrm{LS}-5^{\circ} \mathrm{LU}$, dimana anomali positif mengindikasikan terjadinya El Nino. Fenomena La Nina ditandai dengan menurunnya suhu permukaan laut pada bujur $170^{\circ} \mathrm{BB}-120^{\circ} \mathrm{BB}$ dan pada lintang $5^{\circ} \mathrm{LS}-5^{\circ} \mathrm{LU}$ dimana anomali negatif, sehingga sering juga disebut sebagai fase dingin. 
Kedua fenomena di perairan pasifik ini memberikan dampak yang signifikan bagi kehidupanmanusia.

Indonesia sebagai rangkaian kepulauan di khatulistiwa yang diapit oleh dua benua dan dua lautan, memiliki cuaca dan iklim yang dapat dikatakan sebagai superposisi dari berbagai macam sirkulasi atmosfer di atasnya yang disebabkan oleh letak geografis tersebut. Gangguan pada salah satu sistem sirkulasi ini akan memberi dampak terhadap cuaca dan musim di Indonesia terutama terhadap curah hujan yang merupakan elemen cuaca dominan. Evaluasi yang dilakukan oleh Badan Meteorologi dan Geofisika terhadap curah hujan selam musim 1997/1998 menyatakan bahwa el nino mempunyai dampak yang paling buruk walaupun el nino ini bukan yang terbesar dalam abad ini (BMG, 1998). Sedangkan bila el nino longsor.

\subsection{El Nino}

Sel sirkulasi vertikal disebut sebagai sirkulasi Walker, yang melengkapi gerak naik di barat dan turun di timur dengan pergerakan ke arah timur di troposfer atas. Perubahan kecil pada pola normal suhu permukaan laut di Pasifik barat menyebabkan perubahan dalam musiman angin permukaan timuran sepanjang ekuator. Perubahan angin biasanya terlihat sebagai anomaly baratanyang menguatkan pertumbuhan anomaly suhu permukaan laut dan anomali suhu permukaan laut dan angin merambat ke arah timur untuk meningkatkan kondisi El Nino. Selama fase dewasa El Nino, anomali sirkulasi walker muncul berlawanan dengan kondisi normalnya, konveksi di barat ditekan dan di bagian timur menguat. Setelah konveksi menurun di Pasifik barat, El Nino menyebabkan kondisi yang lebih kering di Indonesia (Bahera,2004).

\subsection{La Nina}

Pada saat terjadi La Nina angin passat timur yang bertiup di sepanjang Samudra Pasifik menguat ( Sirkulasi Walker bergeser ke arah Barat ). Sehingga massa air hangat yang terbawa semakin banyak ke arah Pasifik Barat. Akibatnya massa air dingin di Pasifik Timur bergerak ke atas dan menggantikan massa air hangat yang berpindah tersebut, hal ini biasa disebut upwelling. Dengan pergantian massa air itulah suhu permukaan laut mengalami penurunan dari nilai normalnya. La Nina umumnya terjadi pada musim dingin di Belahan Bumi Utara Khatulistiwa.

Kondisi ini mengakibatkan adanya pusat tekanan tinggi di atas Pasifik tengah sekitar ekuator, dengan konsekuensi pergeseran sel sirkulasi zona dimana pada pusat tekanan 
tinggi subsidensi dan udara bergerak ke arah bawah, sedangkan di bagian lain untuk mengimbangi gerak subsidensi ini terjadi konveksi (udara bergerak ke arah atas). Khusus untuk Indonesia, kondisi ini akan mengakibatkan aktifitas awan konvektif yang mengakibatkan meningkatnya jumlah curah hujan. Untuk menyatakan intensitas La Nina dipakai anomali suhu laut pada daerah ElNino.

Faktor Penyebab

1. Anomali suhu yang mencolok di perairan samuderapasifik.

2. Melemahnya angin passat (trade winds) di selatan pasifik yang menyebabkan pergerakan angin jauh darinormal.

3. Kenaikan daya tampung lapisan atmosfer yang disebabkan oleh pemanasan dari perairan panas dibawahnya. Hal ini terjadi di perairan peru pada saat musimpanas.

4. Adanya perbedaan arus laut di perairan samuderapasifik.

Pada saat normal angin passat bertiup dari tekanan tinggi Sub Tropis dari arah timur menuju tekanan rendah ekuator barat. Sehingga air hangat samudera pasifik berkumpul di pantai barat Australia dan pantai indonesia. Hal inilah yang mengakibatkan hujan di Australia dan indonesia. Namun pada dua tahun sampai tujuh tahun sekali Angin passat tersebut berubah arah. yang semula dari arah timur ke barat berubah menjadi arah barat ke arah timur. Hal inilah mengakibatkan el nino yaitu di samudera pasifik dan indonesia berkurang curah hujan dari biasanya. Kemudian untuk la nina terjadi karena angin passat bertiup dengan kencang dan terus menerus melewati samudera pasifik menuju Australia. Angin passat ini akan mendoronglebih banyak air hangat di samudera pasifik menujuAustralia barat sehingga hujan banyak turun di samudera pasifik barat, Australia barat dan indonesia

\section{Proses Terjadinya}

Terjadinya El nino Pada bulan Desember, posisi matahari berada di titik balik selatan bumi, sehingga daerah lintang selatan mengalami musim panas. Di Peru mengalami musim panas dan arus laut dingin Humboldt tergantikan oleh arus laut panas. Karena kuatnya penyinaran oleh sinar matahari perairan di pasifik tengah dan timur, menyebabakan meningkatnya suhu dan kelembapan udara pada atmosfer. Sehingga tekanan udara di pasifik tengah dan timur rendah, yang kemudian yang diikuti awan-awan konvektif (awan yang terbentuk oleh penyinaran matahari yang kuat). Sedangkan di bagian pasifik barat tekanan udaranya tinggi yaitu di Indonesia (yang pada dasarnya dipengaruhi oleh angin muson, angin pasat dan angin lokal. Akan tetapi pengaruh angin 
muson yang lebih kuat dari daratan Asia), menyebabkan sulit terbentuknya awan. Karena sifat dari udara yang bergerak dari tekanan udara tinggi ke tekanan udara rendah. Menyebabkan udara dari pasifik barat bergerak ke pasifik tengah dan timur. Hal ini juga yang menyebabkan awan konvektif di atas Indonesia bergeser ke pasifik tengah dantimur.

Sedangkan La Nina sebaliknya dari El Nino, terjadi saat permukaan laut di pasifik tengah dan timur suhunya lebih rendah dari biasanya pada waktu-waktu tertentu. Dan tekanan udara kawasan pasifik barat menurun yang memungkinkan terbentuknya awan. Sehingga tekanan udara di pasifik tengah dan timur tinggi, yang menghambat terbentuknya awan. Sedangkan di bagian pasifik barat tekanan udaranya rendah yaitu di Indonesia yang memudahkan terbentuknya awan cumulus nimbus, awan ini menimbulkan turun hujan lebat yang juga disertai petir. Karena sifat dari udara yang bergerak dari tekanan udara tinggi ke tekanan udara rendah. Menyebabkan udara dari pasifik tengah dan timur bergerak ke pasifik barat. Hal ini juga yang menyebabkan awan konvektif di atas pasifik ttengah dan timur bergeser ke pasifik barat.

\section{Dampak Dan Pengaruh}

Episode panas dan dingin variasi tahunan temperatur permukaan laut samudra pasifik bagian tengah dan timur sekitar ekuator ternyata berkaitan dengan anomali atmosfer skala regional dan global. Anomali temperatur positif disamudra pasifik disekitar ekuator disebut El Nino, yang mempunyai efek terhadap sirkulasi atmosfer skala besar. Fenomena ini ternyata mempunyai korelasi yang sangat erat dengan osilasi atmosfer global yang dikenal dengan Osilasi Selatan (OS). Pasifik sebelah timur berada dibawah nilai kondisi normal dan nilai tekanan udara di atas wilayah indonesia dan bagian utara australia berada di atas nilai kondisi normal. Kondisi ini merupakan karakter dan fasa panas osilasi selatan, sehingga seringkali fenomena ini disebut juga episode el nino Southem Oscillation ( ENSO).

Sebaliknya pada waktu temperatur muka laut pada daerah termaksud lebih dingin dan dari keadaan normal ( fasa dingin osilasi selatan yang dikenal sebagai la nina ), diamati hal yang sebaliknya yaitu bahwa tekanan udara diatas wilayah indonesia dibawah nilai normal dan diatas normal diamati dibagian timur samudra pasifik. Selama el nino dan la nina berlangsung terjadi gangguan terhadap pola hujan daerah tropis. Selain itu, fenomena ini juga mempengaruhi bentuk sirkulasi atmosfer seperti jet stream sub tropis dan musim dingin daerah lintang sedang. Jet stream sub tropis diatas samudra pasifik akan menguat selama fasa panas berlangsung dan sebaliknya melemah pada episode 
dingin. Perubahan intensitas jet stream subtropics menyebabkan gangguan terhadap sistem badai extratropis dan sistem front yang mempengaruhi kemunculan anomali temperatur dan curah hujan berbagai daerah lintang menengah. Untuk daerah tropis, pergeseran aktivitas badai hujan dari wilayah indonesia ke Samudra Pasifik bagian tengah mengakibatkan kondisi kering yang abnormal diatas australia utara, Indonesia dan Filipina. Pada episode dingin, temperatur muka laut samudra pasifik bagian tengah yang lebih dingin dan biasanya akan mengahalangi pembentukan awan hujan di atasnya dan kondisi lebih basah atau hujan diatas normal akan berkembang hingga kesebelah barat Australia utara dan Indonesia selama musim dingin di Belahan Bumi Utara (BBU), dan Filipina selama musim panas BBU.

\section{a. Pada Alam}

Untuk Indonesia, ketika El nino berlangsung, musim kemarau menjadi sangat kering serta permulaan musim hujan yang terlambat. Sedangkan ketika La nina, musim penghujan akan tiba lebih awal dari biasanya. Naiknya tekanan udara di pasifik tengah dan timur saat El Nino, menyebabkan pembentukan awan yang intensif. Hal ini yang menjadikan curah hujan yang tinggi di kawasan pasifik tengah dan timur. Sedangkan sebaliknya, di daerah pasifik barat terjadi kekeringan yang jauh dari normal. (Gambar 5. Dampak El Nino)

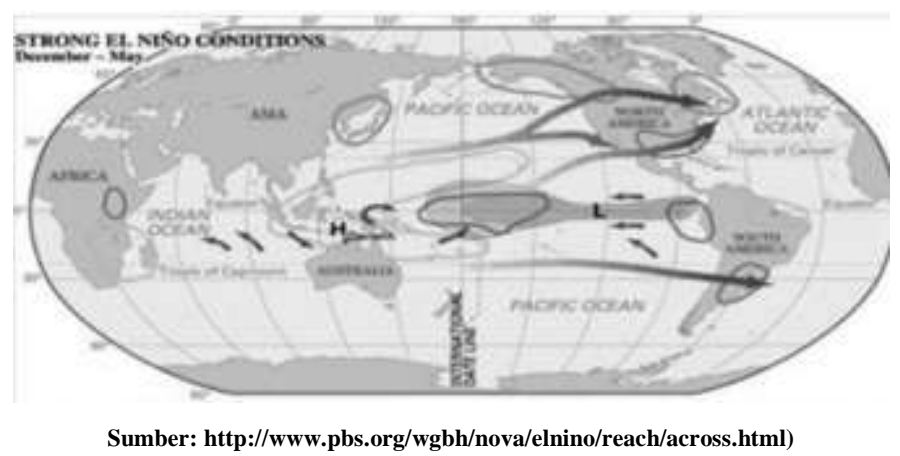

Fenomena El Nino menyebabkan curah hujan di sebagian besar wilayah Indonesia berkurang, tingkat berkurangnya curah hujan ini sangat tergantung dari intensitas El Nino tersebut. Namun karena posisi geografis Indonesia yang dikenal sebagai benua maritim, maka tidak seluruh wilayah Indonesia dipengaruhi oleh fenomena El Nino.

El Nino pernah menimbulkan kekeringan panjang di Indonesia. Curah hujan berkurang dan keadaan bertambah menjadi lebih buruk dengan meluasnya kebakaran hutan dan asap yang ditimbulkannya. (Gambar 6. Dampak La Nina) 


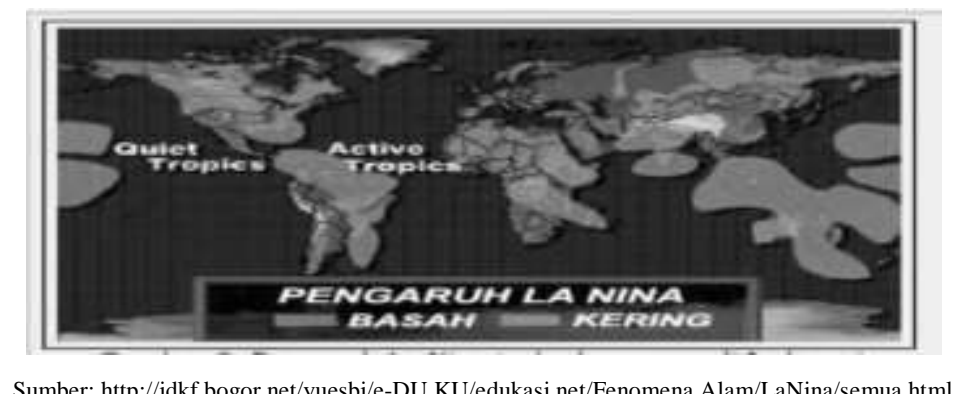

Turunnya tekanan udara di pasifik tengah dan timur saat La Nina, menjadi hambatan terbentuknya awan di daerah ini, sehingga mengalami kekeringan. Sedangkan sebaliknya, di daerah pasifik barat curah hujan sangat tinggi. Hal ini menimbulkan banjir yang parah di Indonesia.

\section{b. Pada Manusia}

Meningkatnya suhu permukaan laut yang biasanya dingin di perairan, mengakibatkan perairan yang tadinya subur akan ikan menjadi sebaliknya. Hal ini menyebabkan nelayan kesulitan mendapatkan ikan di perairan. Selama elnino 1982 1983 dicatat adanya perjangkitan terbatas penyakit kolera diseluruh wilayah indonesia akibat pengaruh kekeringan terhadap ketersediaan airbersih.

\section{Efek El Nino Dan La Nina}

\section{a. Perubahan Iklim}

Trenberth, Houghton and Filho (1995) dalam Irawan (2006) mendefinisikan perubahan iklim sebagai perubahan pada iklim yang dipengaruhi langsung atau tidak langsung oleh aktivitas manusia yang merubah komposisi atmosfer yang akan memperbesar keragaman iklim teramati pada salah satu akibat dari penyimpangan iklim adalah terjadinya fenomena El-Nino dan La-Nina.

Fenomena El-Nino akan menyebabkan penurunan jumlah curah hujan jauh di bawah normal untuk beberapa daerah di Indonesia. Kondisi sebaliknya terjadi pada saat fenomena La-nina berlangsung. Cuaca dan iklim muncul setelah berlangsung suatu proses fisik dan dinamis yang kompleks yang terjadi di atmosfer bumi. Kompleksitas proses fisik dan dinamis di atmosfer bumi ini berawal dari perputaran planet bumi mengelilingi matahari dan perputaran bumi pada porosnya. Pergerakan planet bumi ini menyebabkan besarnya energi matahari yang diterima oleh bumi tidak merata, sehingga secara alamiah ada usaha pemerataan energi yang berbentuk suatu sistem peredaran udara, selain itu matahari dalam memancarkan energi juga bervariasi atau berfluktuasi dari waktu ke waktu (Taufik, dkk,2011). 
Perpaduan antara proses-proses tersebut dengan unsur-unsur iklim dan faktor pengendali iklim menghantarkan kita pada kenyataan bahwa kondisi cuaca dan iklim bervariasi dalam hal jumlah intensitas dandistribusinya.

\section{b. Sebab-Sebab Perubahan Iklim}

Pertambahan jumlah penduduk bumi yang berhubungan secara langsung dengan penambahan gas rumah kaca secara global. Kegiatan manusia dalam penggunaan energi bahan bakar fosil serta kegiatan alih-guna-lahan dan kehutanan. Karbon dioksida (CO2) yang kontribusi terbesar berasal dari negara industri.

Hujan Sulit Diprediksi. Menurut beberapa ahli telah terjadi perubahan iklim yang salah satu indikasinya adalah perubahan pola hujan. Tapi ada beberapa ahli yang menyatakan belum terjadi perubahan iklim karena, perubahan pola hujan ini masih dalam taraf perubahan variabilitas saja akibat adanya anomali-anomali iklim seperti siklon tropis dan kejadian El Nino dan La Nina. Hujan dipandang sebagai salah satu variabel peramalan cuaca dan iklim yang sagnat penting karena mempengaruhi aktivitas kehidupan manusia di berbagai sektor seperti pertanian, perhubungan, perdagangan, kshtan, lingkungan hidup, dll. Namun hujan merupakan salah satu variabel atmosfer yang paling sulit diprediksi dan pada saat ini masih merpkan tantangan yang besar bagi para peneliti meteorologi.

\section{Hubungan El Nino La Nina Terhadap Iklim Dan Eksplanasi Ilmiah}

Iklim adalah kondisi rata-rata cuaca berdasarkan waktu yang panjang untuk suatu lokasi di bumi atau planet lain. Iklim di Indonesia tidak akan selalu berjalan secara normal setiap tahunnya, ada suatu saat terjadi penurunan curah hujan namun disaat yang lain terjadi curah hujan yang tinggi sehingga menyebabkan banjir. Menjadikan sesuatu yang penjelasan dengan konsep benar di perlukan eksplanasi ilmiah menggunakan teori dan hukum ilmiah sebagai dasar untuk memberikan jawaban yang rasional atas pertanyaanpertanyaan atau untuk menerangkan mengapa fenomena terjadi. Sebagian masyarakat beranggapan bahwa terjadinya banjir dan kemarau panjang diakibatkan oleh dosa-dosa manusia, diantaranya adanya berjudi, membunuh, merampok dll. Hal ini membutuhkan eksplanasi ilmiah untuk merubah anggapan masyarakat tentang iklim.

Eksplanasi ilmiah harus memenuhi dua syarat sistematik yaitu syarat relevan eksplantori dan syarat testabilitas. Episode panas dan dingin variasi tahunan temperatur permukaan laut samudra pasifik bagian tengah dan timur sekitar ekuator ternyata berkaitan dengan anomali atmosfer skala regional dan global. Anomali temperatur positif 
disamudra pasifik disekitar ekuator disebut El Nino, yang mempunyai efek terhadap sirkulasi atmosfer skala besar, Sebaliknya pada waktu temperatur muka laut pada daerah termaksud lebih dingin dan dari keadaan normal ( fasa dingin osilasi selatan yang dikenal sebagai la nina ), diamati hal yang sebaliknya yaitu bahwa tekanan udara diatas wilayah indonesia dibawah nilai normal dan diatas normal diamati dibagian timur samudra pasifik. Penjelasan tersebut memenuhi syarat pertama eksplanasi ilmiah dengan menggunakan pengertian El Nino La Nina sebagai penjelasan mengapa fenomena terjadi. Fenomena El-Nino akan menyebabkan penurunan jumlah curah hujan jauh di bawah normal untuk beberapa daerah di Indonesia. Kondisi sebaliknya terjadi pada saat fenomena La-nina berlangsung, hal ini memenuhi syarat kedua eksplanasi ilmiah sebagai penjelasan akibat suatu fenomena terjadi.

Selama ini masyarakat kurang memahami mengapa terjadinya perubahan iklim, sebagian masyarakat menganggap bahwa perubahan iklim diakibatkan oleh dosa dan maksiat yang dilakukan masyarkat yang penuh dosa. Cuaca dan iklim muncul setelah berlangsung suatu proses fisik dan dinamis yang kompleks yang terjadi di atmosfer bumi. Kompleksitas proses fisik dan dinamis di atmosfer bumi ini berawal dari perputaran planet bumi mengelilingi matahari dan perputaran bumi pada porosnya. Pergerakan planet bumi ini menyebabkan besarnya energi matahari yang diterima oleh bumi tidak merata, sehingga secara alamiah ada usaha pemerataan energi yang berbentuk suatu sistem peredaran udara, selain itu matahari dalam memancarkan energi juga bervariasi atau berfluktuasi dari waktu ke waktu (Winarso,2003).

Perpaduan antara proses-proses tersebut dengan unsur-unsur iklim dan faktor pengendali iklim menghantarkan kita pada kenyataan bahwa kondisi cuaca dan iklim bervariasi dalam hal jumlah intensitas dan distribusinya. Hal ini sesuai dengan hakikat dari pembuktian keilmuan adalah keperyaan bahwa suatu pernyataan dan pengertian mempunyai peluang besar untuk terbukti atau benar.

\section{KESIMPULAN}

Peristiwa El Nino dan La Nina merupakan fenomena alam yang terjadi di perairan samudera pasifik. Yang kedua-duanya menyebabkan bencana pada daerah di sekitar perairan samudera pasifik. Daerah satu mengalami curah hujan yang sangat tinggi sehingga menyebabkan banjir, sedangkan daerah satunya mengalami kekeringan yang luar biasa. Yang menakutkan peristiwa El Nino dan La Nina tidak dapat dihindari akan 
tetapi dapat terdeteksi, sehingganegara-negara yang berada di sekitar samudera pasifik sebaiknya melakukan persiapan untuk mitigasi bencana.

Anggapan masyarakat bahwa fenomena terjadinya banjir dan kekeringan diakibatkan oleh dosa-dosa perbuatan manusia, hal ini memerlukan sesuatu yang penjelasan dengan konsep benar di perlukan eksplanasi ilmiah menggunakan teori dan hukum ilmiah sebagai dasar untuk memberikan jawaban yang rasional atas pertanyaanpertanyaan atau untuk menerangkan mengapa fenomena terjadi.

Eksplanasi ilmiah harus memenuhi dua syarat sistematik yaitu syarat relevan eksplantori dan syarat testabilitas. Episode panas dan dingin variasi tahunan temperatur permukaan laut samudra pasifik bagian tengah dan timur sekitar ekuator ternyata berkaitan dengan anomali atmosfer skala regional dan global. Anomali temperatur positif disamudra pasifik disekitar ekuator disebut El Nino, yang mempunyai efek terhadap sirkulasi atmosfer skala besar, Sebaliknya pada waktu temperatur muka laut pada daerah termaksud lebih dingin dan dari keadaan normal ( fasa dingin osilasi selatan yang dikenal sebagai la nina ), diamati hal yang sebaliknya yaitu bahwa tekanan udara diatas wilayah indonesia dibawah nilai normal dan diatas normal diamati dibagian timur samudra pasifik. Penjelasan tersebut memenuhi syarat pertama eksplanasi ilmiah dengan menggunakan pengertian El Nino La Nina sebagai penjelasan mengapa fenomena terjadi. Fenomena El-Nino akan menyebabkan penurunan jumlah curah hujan jauh di bawah normal untuk beberapa daerah di Indonesia. Kondisi sebaliknya terjadi pada saat fenomena La-nina berlangsung, hal ini memenuhi syarat kedua eksplanasi ilmiah sebagai penjelasan akibat suatu fenomenaterjadi.

\section{DAFTAR PUSTAKA}

Accaps. 2016. Skenario-Dampak El Nino La Nina Di Indonesia. www.acaps.org

Behera, S. K., Luo, J.J., Masson, S., Jury, M. R., and Rao, S. A. (2004). Coupled

Ocean-Atmosphere Variability in the Tropical Indian Ocean. AGU Book OceanAtmosphere Interaction and Climate Variability, C. Wang, S.-P. Xie and J.A. Carton (eds.), Geophys. Monogr., 147,

Irawan. B. 2006. Fenomena Anomali Iklim El Nino dan La Nina KEcendrungan Jangka Panjang Dan Pengaruhnya Terhadap Produksi Pangan. Forum Penelitian Agro Ekonomi. Volume 24 No. 1, Juli 2006: 28-45. 
Taufiq \& Marnita. 2011. IPBA (Imu Pengetahuan Bumi dan Antariksa). Universitas Almuslim.

Tjasyono. B. 2004. Klimatologi. Bandung: Penerbit ITB 